\title{
現実共有論への一視角
}

——社会的表象研究における認知的多相論の検討

\section{Toward a New Perspective of the Shared Reality Theory:}

An Examination of Discussions about "Cognitive Polyphasia" in Social Representations Studies

\section{熊 谷 有 理 KUMAGAI Yuri}

The aim of this paper is to present a new perspective of shared reality theory. Sharing realities, that is to say, a shared orientation toward and acting together in the world with others has been conceived substantialistically. However, some problems remain. The paper organizes ideas for thinking about sharing reality through an examination of some major discussions about "cognitive polyphasia" in social representations studies. In this way, a relationalistic perspective on shared reality theory will be presented.

\section{1. はじめに}

現実の共有、すなわち、私たちが他者とともに世界に志向し行為することは、集合的現 象の基礎にあるものとされてきた。そして、現実の共有は、2通りの仕方で議論されてき た。一方で、個々人の経験から出発し、様々な経験や認識の間で同一性が確立されること として、現実の共有を考察する議論がある。典型的なものはA. Schützの研究である。 Schützの著作では、各々の観点からそれぞれの仕方で経験している自己と他者とが互い に観点を取得し合いながら間主観的な意味を構成することが、現実の共有として論じられ ている [Schütz 1932=1982]。他方、個々人を越えた集合体の経験から出発し、様々な経 験や認識が統合され行動が相互調整されることとして、現実の共有を考察する議論があ る。たとえば、Schützの理論をDurkheimの集合表象概念によって補いながら展開したP. Berger と T. Luckmannの著作では、集団に「共有された表象」（共通のスキーマ、枠組） を通して人々が彼らの経験を構成し、コミュニケーションが可能になることが、現実の共 有として考察されている [Berger \& Luckmann 1966=2003]。

けれども、これらの現実共有論には、次のような問題点が指摘されてきた。まず、(1)自 己と他者とが各々の内的領域で異なる仕方で現実を経験しているという前提から出発する かぎり、経験同士の相違を乗り越えることは原理的に不可能という問題がある。この独我 論的前提に由来する困難は、自己と他者との間に「共有された表象」があると想定するな らば、ひとまずは回避できる ${ }^{(1)}$ 。しかしその場合も、(2)「共有された表象」とは何か、そ のようなものが存在するのか、存在するとすればどこに・どのような仕方で存在するのか (e.g. 個人の「頭の中」で使用される記号体系としてあるのか、個人を取り囲む制度的環 境としてあるのか）といった問題や「共有された表象」を認識することに関わる問題（「共 有された表象」をめぐる存在論的・認識論的諸問題) が残る [Harré 1998]。そして、仮 に「共有された表象」と呼ばれるものが存在するとしても、それが実際にどのように適用 
されているのか、スキーマであれ表象であれ何かが共有されているように見えるときに実 際にどのようなことが起こっているのか、といったことが明らかにされる必要がある。だ が、こうした(3)行為やコミュニケーションの具体的様相を明らかにする研究がほとんど不 在であることも、指摘されてきた [Harré ibid.]。

以上の問題点は、現実共有論の存在論的基礎の見直しが必要であることを示唆してい る。従来の議論は、個人の心理的過程や集合体の規範に導かれた社会的な意味産出過程に 定位して、現実の共有がなぜ・いかにして成立するのかという問いを探究してきた。しか し、この問いに対する十分に説得的な解答は、今のところ得られていない。個人の心理的 過程から出発するアプローチには、独我論的前提に由来する困難が常につきまとう。他方、 集合体に由来する社会的な意味産出過程に注目するアプローチは、スキーマであれ表象で あれ共通の何かに人々がコミットし調和的に自らの行為を導く過程に関する説明を欠くな らば、論点先取や同語反復に陥る。この隘路を解決する1つの方法は、現実の共有という 事態の背後に経験や認識の同一化や統合を導く心理的・社会的な要因や過程を想定する実 体論的視点から自由になること、である。そして、行為やコミュニケーションに定位し、

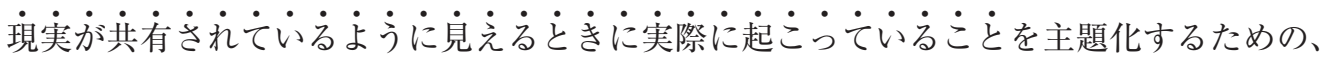
新たな視角を構築する必要がある ${ }^{(2)}$ 。

そこで本稿では、社会的表象理論（以下、SRT）において「認知的多相 (cognitive polyphasia)」という用語を使用して展開されてきた議論から、このような視点転換のた めの手がかりを得ることにしたい ${ }^{(3)}$ 。SRTの提唱者であるS. Moscoviciは、1950年代のフ ランス社会に精神分析が普及する過程を分析し、次のことを指摘した。社会に普及する過 程で精神分析は、人々の会話のトピックとなり、日常的なコミュニケーションがその周り で営まれるような慣習的な対象へと変容していった。しかし、会話の中で精神分析は、「フ ロイトの科学理論」であると同時に「ブルジョワ科学」でもあり、「イデオロギー」や「『告 解』の新しい形式」でもあった。また、自己や他者を理解するための解釈図式として、精 神分析的な観念が暗黙的に使用される過程も見られた。その結果、精神分析の周囲で多様 な経験や認識が次々と産み出されていった。この発見をもとにMoscoviciは、ある仮説を 提出した。同一の集団やコミュニティで多様な経験や認識が一致することも統合されるこ ともなくただ併存す方状態を日常的思考の「正常なあり方 (rule)」とみなす、「認知的多 相の仮説」である [Moscovici 2008: 191]。

認知的多相は現在もほぼ未分化な発想である。しかしこの発想は、多様な経験や認識が 併存する状態で会話やコミュニケーションが滞りなく進行することに注意を喚起するため に、上述した視点転換のための端緒となりうる。近年、SRTでは、個人や集合体に存在 論的基礎を置くことなく、コミュニケーションに焦点をあてて、表象や現実構成という現 象を考察するための理論的整備が進められている [cf. Voelklein \& Howarth 2005]。本稿 では、この理論的潮流において中心的な役割を果たしている S. Jovchelovitch、W. Wagner、G. Duveenの認知的多相論を検討しながら、現実の共有という事態を考えるた めの発想を整理する。そして、この課題に取り組むことを通じて、現実共有論の新たな視 角を提示したい。 


\section{2.「現実を共有する」とはどのようなことか—Jovchelovitchの認知的多相論と 表象論}

\section{（1）個別認識間の同一性—Jovchelovitch の認知的多相論}

以下ではまず、個人や主体の主観的意味と意味構成の間主観性を強調するSchütz と類 似の視点から認知的多相論を展開している、Jovchelovitchの論考を検討する [Jovchelovitch $2007: 44]$ 。

Jovchelovitchはホームレスの生活環境と公衆衛生に関する支援を行うロンドンの非営 利団体（Homelessness Professionals、以下HPs）を対象として、ホームレスに関する知 識と実践が構築される過程を明らかにするための調查を実施した [Renedo \& Jovchelovitch 2007]。イギリスのホームレス支援の構造は、法定代理人である公共セク ターとHPsを含む非法定代理人である第三セクターの双方にまたがっている。そのため、 ロンドンには「ホームレス (Homelessness)」が何を意味するか（「屋根なし」／より多様 な状況）、どのような人たちがホームレスと呼ばれる集団に所属するのか（意図性の有無 で判断する/判断しない)、そして、この社会問題の最良の解決策は何か（住環境や食生 活の改善／職業訓練等の自立に向けた継続的援助）に関する、異なる意見と見方が存在し ている。

JovchelovitchによればHPsは、ホームレスという対象や行為の状況に関する異なる意 見や見方が存在する状況で活動していくために、次のような課題に直面する。それは、 ホームレスを管理対象として客体化・被害者化しょうとする公共セクター側の圧力と要請 に対処しながら、同時に、第三セクターとして自らが揭げる独自の理念のもとでホームレ スの人格を尊重したアプローチを保持する、という課題である。そして、この課題に対処 するためにHPsのホームレス表象には、様々な知識や価值、実践のパッチワークによっ て構成される多面的で矛盾する要素の併存という認知的多相の特徴が見られるという。

では、上述の議論に扔いて現実の共有は、どのようなものとして考えられているのだろ うか。まず、Jovchelovitchは現代社会に特有の〈認識の多元性〉、すなわち対象や世界に 対する様々な認識の可能性があることを、現実の共有のために解決を要する問題状況とし て記述する。現代の社会空間には様々な伝統や専門を持ち、様々な社会的位置を占める個 人や集団の多様な知識と観点が存在している [ibid. : 783]。そこでは、いかなる知識や観 点も人々にとって共通の真理を表象するための自明な正当性を持ち得ず、共通認識の構成 過程は論争的なものとならざるを得ない。そして、Jovchelovitchによれば、こうした〈認 識の多元性〉に対処するための認知的資源を与えているのが、認知的多相である。HPsの スタッフによる次の発言を例に考えてみよう。

「HPsのスタッフといっても、街で暮らすホームレスたちと実際に接したことがなければ、ホーム レスについて二重のイメージ〔自尊心を持つ一個の個人/問題を抱えた被害者〕を持っていても おかしくはないと思います。つまり、ホームレスというのは、地下鉄の駅の傍で野宿している人 たちのことであって、だから、ホームレスは、ほら、その、私のクライアントのように、〔薬物依 存治療のための]病院や特別な施設から出てきたばかりの人たちという、ね」

Jovchelovitchによればこの発言は、HPsの人々が多相的な表象を構成することで社会空 間に存在する様々な他者の意見や観点にアクセスし、他者の観点から対象や行為の状況を 認識していることを示している。そして、このように他者の観点を取得することによって、 
人々は彼らの認識や行為を他者の認識や行為との関係で正当化するという言説的な実践を 達成できるという [ibid. : 787]。

以上から明らかなとおり、Jovchelovitch は認知的多相論で、なぜ・いかにして認識の 同一性が成り立つのかという問いに指向し、Schützと同じょうにその解答を他者の観点 取得に基づく間主観的意味構成に求めた。もちろん、他者の観点取得は独立した観点を持 つ主体の存在を前提とするため、Jovchelovitchの議論もまた必然的に独我論的前提に由 来する困難を抱えこむ（問題点(1)）。だが、この困難に対する明白な解決策は示されてい ない。Jovchelovitchは他者の観点取得の重要性を強調するものの、それが可能になる具 体的過程についてはほとんど何も述べていないのである（問題点(3)）。

\section{（2）表象の個体発生一Jovchelovitchの表象論}

一方、Jovchelovicthの表象論では「表象の個体発生」という発想のもと、前項で検討 した認知的多相論の前提を覆すような議論が展開されている。表象の個体発生とは、個人

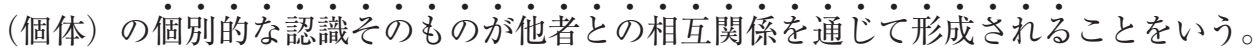

表象の個体発生という発想は、J. Piagetの「脱中心化」論に拠りながら提示されてい る ${ }^{(4)}$ 。脱中心化が始まる最初の段階（前操作期：2〜 7歳頃）では、幼児は彼（より適切に は彼の身体）の前で生じるすべての物事を直観的に理解している。幼児は自分で得た知覚 情報のみによって状況を理解しており、現在以外の過去や未来、他者の視点や立場に立っ て対象や世界について考えることはできない。しかし、言語や思考の能力を獲得するにつ

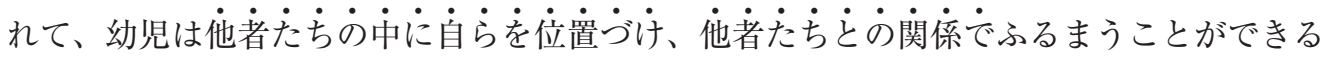
ようになる。たとえば、ごっこ遊びや「保存」の概念、時制の習得によって、幼児は他者 の役割との関係で特定の役割を演じたり、未来の状態との関係で現在の行動を統制したり できるようになる。そして、この過程を通して、幼児は他者および他者たちと共有された 世界を自らの「外部」として経験する（「内的リアリティ」を持つ）「自己」を構築すると いう。このようにPiagetの脱中心化論では、幼児の自己やその個別的な認識が、他者や 他者と共有された世界との関係を通して規定され構成される過程に焦点があてられる。表 象の個体発生という発想は、個々の認識をそれぞれの独自の観点を持つ自己の所与の属性 としてではなく、それ自体、他者との関係を通して規定され形成されるものとして考える 発想なのである。

ここで、表象の個体発生という発想によって、既存の現実共有論の問いの立て方が再考 を迫られることに注意しょう。表象の個体発生という発想によれば、独自の観点やその観 点を属性として有する個人主体（自己）がはじめに存在するのではない。個別的な認識や 観点そのものが人々が位置する（=他者との関係で自己になる）様々な関係性の中で規定 され形成されるために、自己が他者とは無関係に独立した観点を持つことなどあり得な い。従って、この発想によれば、いかにして自己が（彼とは異なる仕方で対象や世界を経 験し認識する）他者の観点を取得し、他者と同一の仕方で経験し認識することができるの かという問題そのものが、疑似問題として退けられることになる。表象の個体発生という 発想は、個人主体やその心的状態に先行し、それらを規定する関係性の領域に注意を喚起 するために、実体論的ではない仕方で現実共有論を再構成しようとする本稿の試みにとっ て示唆的である。

とはいえ、Jovchelovitch自身はこの発想を十分に展開することができなかった。 
Jovchelovitchによれば個別認識が関係性の中で規定され形成される過程は、自己と他者 とが互いに観点の差異を認め合う「観点の承認」の過程を通して可能になる [Jovchelovitch 2007 : 133]。けれども、他者の観点取得の可能性をめぐる問いと同様に、いかにして自己 と他者とが互いに観点の差異を認め合うことができるかという観点の承認の可能性をめぐ る問いもまた、各々固有の独立した観点を持つ主体の先在性を前提とする。結局、自己一 他者という哲学・心理学の伝統的カテゴリを使用することによって、Jovchelovitchは、 関係性の領域よりも規定的な水準に個人主体とその心的状態を位置づけてしまうのであ る。

では、こうした個人主義的な誤謬を回避しながら、個別認識が規定され形成される関係 性の領域に関する上述した発想を展開するには、どうすればよいか。次節ではSRTの他 の論者たちの著作を検討しながら、そのためのアイデアを探求する。

\section{3. 行為における現実の共有—Wagner とDuveen の認知的多相論}

\section{(1)「行為のための仮説」としての「共有された表象」一Wagnerの認知的多相論}

まず、個別認識の形成過程に焦点をあてるWagnerの認知的多相論を検討してみょう。 北インドの都市パトナにおける精神病の表象を調査したWagnerは、人々にとって「新奇 なもの」であった精神病の近代的観念（＝「精神疾患（mental illness）」）が社会に普及し、 共通の現実として構成される過程を考察した [Wagner et al. 1999, 2000]。

精神病の近代的観念が共通の現実として構成される過程は、次のように説明されてい る。パトナでは患者の家族内の私的文脈と家族外の公的文脈とで、精神病が異なる仕方で 定義され、異なる治療が行われていた。家族内の私的文脈において精神病は、患者の対面 する状況によって引き起こされる患者自身の個人的反応（e.g. 結婚生活や家庭生活に対す る不満）として理解されている。そのため、私的文脈では、家族内での会話や話し合いを 通して、患者自身による各々の状況への対処を支援することが精神病治療の目的とされ る。しかし、症状が深刻化し、私的な治療形式による対処が困難になると、精神病は遺伝 や悪霊といった伝統的な観念やイメージを通して理解され、何らかの家族外的 (extrafamilial）な処置（e.g. 悪霊祓い）の対象として考えられるようになる。このように、家族 の内部と外部とで精神病に関する定義と治療を区別し、その各々の領域における認識と行 動の内容を規定する、「文化的な信念のパターン」がある。精神病の近代的観念は、この「文 化的な信念のパターン」が与える多様な観念 (e.g. 会話、遺伝、悪霊) と価值 (e.g. 家族、 結婚、カースト）から構成されたマトリクスの中で「家族内」の「私的」文脈に位置づけ られることで、インド社会に埋め込まれるという［Wagner et al. 1999：437]。

上の説明からも明らかなように、Wagnerの認知的多相論では、個別認識の形成過程が 焦点化されている。精神病の近代的観念に対する個別的な認識（e.g.「精神疾患の原因は 家庭生活に対する不満である」）は、「文化的な信念のパターン」に従って人々が精神病に ついて語ったり、患者に対処したりすることを通して形成され、そのパターンが与える観 念や価值のマトリクスの中で特定の位置を占めることで内容を規定される。このように、 個別認識を規定・形成する「文化的な信念のパターン」の働きに注目することで、 Wagnerの認知的多相論では、個人主義的な現実共有論に指摘されてきた独我論的前提に 由来する困難（問題点(1)）が回避されている。

一方、Wagnerの議論にとって、「共有された表象」をめぐる存在論的・認識論的諸問 
題（問題点(2)）がよりクリティカルな問題として現れる。Wagnerが「文化的な信念のパ ターン」と呼ぶものは、認識や行為のために使用される集団の共通の解釈図式として機能 しており、その意味で、本稿で「共有された表象」と呼ぶものと等価である。そこで、 Wagnerの議論に対しても、次のような問いが提起されることになる。すなわち、「文化 的な信念のパターン」とは何か、それは存在するのか、存在するとすればどこに・どのよ うな仕方で存在するのか、あるパターンに従う行為と別のパターンに従う行為とを（研究 者が）いかにして区別することができるのか、そのような行為記述の妥当性がいかにして 担保されるのか、という問いである。

結論から言えば、Wagnerは以下で述べる行為論的な表象概念を提出することによって、 上記の存在論的・認識論的諸問題を解消するための道筋を示している [cf. Wagner 1998, 2007]。

まず、Wagnerが現実の共有を脅かす問題状況をどのようなものとして記述しているか、 確認してみよう。コミュニケーションが問題なく進行しているとき、私たちは自分たちが 行っていることが何か、それがどのようなパターンや規則に従っているのか、といったこと に意識を向けることはない。こうしたことが意識の対象となるのは、予期せ好出来事（／新 奇なものとの遭遇）が生じたときである。たとえば、○×ゲームの対戦中に対戦相手が、「格 子の交差点に○印をつける」といった理解不能な行動をしたとしょう。そのとき私は、どの

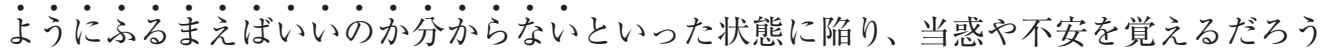
[Garfinkel 1963]。Wagnerが問題状況として記述するのは、このような〈指向性の喪失〉 である。前節で検討したJovchelovitchの著作では、対象の多様な認識がありうること（〈認 識の多元性〉）が問題状況として記述されており、そこで対象の性質を決定する主体の固有 の観点や認識があることは前提とされていた。しかし、Wagner的な問題状況では、対象の 性質犬゙けでなく、対象市性質を決め方度応市性質卞また未分化であり、つまり集団の行為 システムが目的や方向性を欠いた状態にあるとされる [Wagner 1998] ${ }^{(5)}$ 。

そして、Wagnerによれば「共有された表象」は、こうした〈指向性の喪失〉状況に対 処するために精緻化される「仮説」として考えられる。先ほどの○×ゲームの例に戻ろう。 対戦相手の理解不能な行動に遭遇した私は、典型的な動機や理由をその行動に与えること で、相手の行動を理解可能なものにしようとするだろう（e.g.「やれやれ、また彼女のい たずらが始まったか」)。このように、行動に典型的な動機や理由を与えることで、相手の 行動を一定のパ多・シに従方字方し它仮定することができるようになる。そして、この 仮定のもとで他者の行動が理解可能で予測可能なものになることで、私は次の一手を打つ ことができ (e.g. 知らん顔をして妌の外に×印をつける)、ゲームの状況が特定の指向性 を持つものとして再確立される (e.g. ボケの応酬)。このように「共有された表象」を、 他者の行動 (や思考) を理解可能で予測可能なものとするために作られ・支持される暗黙 的な仮説として考えることができる。

さて、「共有された表象」を行為のための仮説とみなす行為論的な表象概念に基いて、 「共有された表象」をめぐる存在論的 ·認識論的諸問題（問題点(2)）について、以下の見 解を導出できる。

まず、次のことに注意しよう。「共有された表象」に関する存在論的問題が有意な問題 として立ち上がるとき、そこには「共有された表象」が対象や世界へ関わる人々の行為を 実体論的・因果的な仕方で方向づけ、決定しているという想定がある（協調的な行為やコ 
ミュニケーションの成立を説明するために、行為やコミュニケーションを決定する「文化 的な信念のパターン」の性質や歴史的起源、社会的分配を問う知識社会学的慣例を考えて みればよい)。しかし、仮説としての「共有された表象」は、実践的推論のための前提と して使用されることで行為を導いているのであって、実体論的・因果的な仕方で行為を決 定するわけではない。

また、「共有された表象」に関わる認識論的問題が有意な問題として立ち上がるとき、 そこでは常に「共有された表象」が仮説として機能している特殊な行為の文脈から切り離 され、対象化されていることに注意したい。そこで「共有された表象」は、当該の行為や コミュニケーションとは別にあり、行為やコミュニケーションを有意味で秩序だったもの にする何かとして考えられている。しかし、行為のための暗黙的な前提＝仮説であり、行 為とその文脈を構成している「共有された表象」は、定義上、対象化されない。もちろん、 予測不能な出来事に遭遇した人々がこれまでの習慣を省みたり、彼らの指向する文脈を意 識的に精査することはある。だが、そのようにして対象化される文脈は、対象化された時 点で既に、人々の行為が従っている仮定＝文脈としての機能を担うものではなくなってい る。

要するに、「共有された表象」をめぐる存在論的・認識論的諸問題（問題点(2)）は、表 象と行為を $2 つ$ 異なる実体や過程とみなす前提に立つかぎりで、「問題」になる。けれ ども、行為論的な表象概念ではこの前提は否定され、表象と行為は 1 つ過程として考え られる。そのため、行為論的な表象概念のもとで、これらの諸問題は解消されるのである。

そして、それは翻って言えば、現実の共有があるかのように見える行為やコミュニケー ションこそが主題化されねばならないということである（問題点(3)）。行為やコミュニケー ションの背後に、現実の共有を成り立たせている何らかの心理的・社会的過程や機制を探 求する必要はない。行為論的な表象概念は、行為と別にある何かとの関係で現実の共有を 実体論的に考察する代わりに、行為に求け方現実の共有を考察するという新たな課題領域 を開くのである。しかしながら Wagner 自身は、仮説構成の適切性に関する実定的基準を 想定し、その基準の起源を集団に求めた。そのため、Wagnerの著作で行為やコミュニケー ションは、集団の（仮説構成の適切性に関する基準を与える）共有された規範や規則、構 造化された文化が不変的な影響力を働かせる過程のようなものとして描かれている。この とき、「共有された表象」は、成員の行為やコミュニケーションから独立にある集団の所 与の属性のようなものとして、再び理解されることになるだろう。以下では、このような 〈表象の歴史因果的実体化〉を回避しながら、行為論的な表象概念を洗練化するためのア イデアを探求する。

\section{（2）明示化行為における「共有された表象」—Duveenの認知的多相論}

Wagnerの共同研究者としてパトナの表象研究に参加したDuveenは、インタビュー調 查の言説資料をもとに認知的多相論を展開した。インタビューで精神病の伝統的治療法と 近代的治療法の各々の効用について質問を受けた参加者たちは皆、伝統的治療法に対する 疑念を表明し、精神科医が施す近代的治療法の方をより信用すると述べていた。しかし、 伝統的治療法が否定され、近代的治療法への支持が表明されるやり方は、様々だった。 Duveenによればこの調査結果は、パトナにおいて精神病に関する多様な認識の併存があ るということだけではなく、その多相性の多様な構成要素同主を関倸ゔ方様交な形式が 
あることを示しているという。次の会話を見てみよう。

I（=Interviewer）：伝統的な治療者たちは技術を持っていると思いますか？

R（=Respondent）：いいえ、そうは思いません。もし、彼らに技術があれば、成功率は $100 \%$ のは ずでしょう。でも、私が思うに、彼らの治療はそんなに成功していません。（以 下、引用内下線部強調は原文ママ) [1]

I：もし、あなたの家族のどなたかが私がさっきお話したような行動〔この地域で精神病の典型的 な行動と見なされているような行動了をし始めたら、どうしますか?

$\mathrm{R}$ ：最先端の治療を受けられる精神科医のところに、彼を連れて行くでしょうね。

I：他にも何かしますか?

$\mathrm{R}$ ：いいえ、何もしません…以前、私のところにいた少年が、病気になったことがありました。周 りの人たちは私に伝統的な治療者のところに彼を連れて行くよう勧めましたが、私は断りまし た。…伝統的な治療法が、伝統的な治療者が、いったい何をしてくれるっていうんでしょう？ 悪霊 (jhar-phook) ですって?ばかばかしい! [2]

たとえば、ケース(1)の回答者は「技術」や「成功率」という「科学的な」（と回答者らが みなす）観念によりながら、異なる2つの治療法を「客観的に」比較することで、近代的 治療法への支持を表明している。ケース(1)の回答者は、伝統的治療法と近代的治療法とを 「科学的」「客観的」に比較可能という意味で等価な治療法として扱っているが、ケース(2) の回答者はそうではない。ケース(2)の回答者は、伝統的治療法の効果や科学的価值そのも のに対する疑念を示すことで、近代的治療法への支持を表明している。

このような認知的多相の形式的多元性への言及は、Duveenの認知的多相論に特殊な関心 を表している。Duveenにとって認知的多相の形式的多元性は、行為やコミュニケーション の特殊な状況と「共有された表象」との密接な繋がりを示す現象であるために、重要であっ た。Duveenは「共有された表象」（Duveenの著作では「文化」とほぼ同義）を、集団の所 与の属性としてではなく、(〈指向性の亦失〉に対処する) 個々の行為に特殊な構造亡形式 を得它作主げられ方発展的現象として理解しょうとしたのである [Duveen 2007 : 551]。

では、Duveenが重視する「行為やコミュニケーションの状況」は、実際にどのような ものとして考察されているのだろうか。Duveenが「特に興味深い」と述べる次のケース に注目してみよう。

「なぜかというと… もし、私の子どもや義理の娘、はたまた私自身の身にそんなこと〔精神病を 患うこと]が起こったならば、私の家族というか、結局、うちに訪れる人たちは皆、マウラヴィ (maulavi)〔ウルドゥー語：聖職者〕に診せてみろと言うに決まっているのです。「パトナにはい いマウラヴィがいるよ。彼をビハール・シャリフ〔パトナの近くの村〕の寺に連れて行くように」っ て。そんな風に皆考元ることは同じなんです。そうでしょう？ですから、私は気が進まなくても、 そして、成功の見込从なんてものがなくても、彼らの言うと拈りにするでしょうね。やっぱり私 はマウラヴィのところへ行くのです。そして、それでも治らなければ、最終手段として医者のと ころへ行き、医者に治療をしてもらいます…」[(3]

「お話したように、それ〔祈祷師による治療の成功〕は私の叔母の身に起こりました。でも、そん なことに意味があるとは思いません。たくさんの人が亡くなっていますし、本にもそういった話 がたくさん載っていますから。ouja（祈䘠師）が患者を吒きすぎて殺してしまったなんて話、あな たも聞いたことがあるでしょう。その人は亡くなりました。それで彼の話は㧍終い。ですから、私 は彼ら〔=ouja〕を少しは信じているけれど、でも信じてはいないんです」[4] 


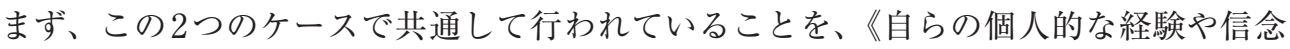

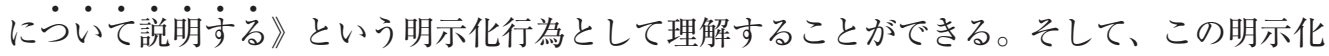
行為のなかで《他者との間で・他者たちによって共有された経験や信念があると文なすす 仮説としての「共有された表象」が働いている。たとえば、ケース(3)の回答者は「私は気 が進まなくても…彼らの言うとおりにするでしょうね」とか「最終手段として医者のもと へ行く」という言葉で、伝統的治療法や近代的治療法に対する自らの信念について述べて いる。そして、このような説明は、《家族」や「うちに訪れる人たち」によって伝統的治 療法に対する信念が共有されている》という仮定のもとで行われている。また、ケース(4) の回答者は「それは私の叔母の身に起こりました。でも、そんなことに意味があるとは思 いません」という言葉で、自らの経験や伝統的治療法に対する自らの疑念について述べて いる。このとき、これらの経験や信念（疑念）は、《私」や「あなた」を含む人々の間で 伝統的治療法に対する共有された一般的な疑念がある》という仮定のもとで説明されてい る（「本にもそういった話がたくさん載っていますから」「oujaが患者を吅きすぎて殺して しまったなんて話、あなたも聞いたことがあるでしょう？」)。

以上のようにDuveenは、個人的な経験や信念について説明する明示化行為で構成され、 その中で働くものとして「共有された表象」を考察している。では、明示化行為との関連 で「共有された表象」について考えることによって、現実の共有という事態についてどの ような発想を得ることができるのだろうか。ここで注意したいことは、明示化行為を通じ て、個別的な経験と共有された経験が分節化される過程があるということである。

上のケースにおいて回答者たちの個別的な経験の内容は、《他者との間で・他者たちに よって共有された経験や信念がある》という仮定を通して、そしてそのようにして誰かに 帰属させられた共有された信念との差異を通して、規定されている ${ }^{(6)}$ 。たとえば、ケース (4)の「それは私の叔母の身に起こりました。でも、そんなことに意味があるとは思いませ ん」という発話について考えてみよう。この発話は単独でみると意味が不明瞭であり、な ぜ叔母の身に起こった治療の成功経験に意味がないと言えるのかは分からない。しかしこ の発話を、「私」と「あなた」(調査者) の間に回答者が仮定する《伝統的な治療法に対す る一般的な疑念》という文脈との関係で考えてみたらどうだろうか。この発話は、《私の 叔母の身に起こった治療の成功体験はあくまで例外的な経験であり一般化できない》とい う意味を持つものとして、理解できるものになる。

また反対に、個別的な経験との差異を通して、共有された経験の内容が規定され形成さ れる過程がある。このことは、明示化行為のもともとの成立構造を考えてみれば、納得で きる。明示化行為では、個別的な経験や信念を他者に対して説明す方こうができるという ことによって、個々の明示化行為が指向する他者たちとの間に共通の文脈が構成されるた めである。たとえば、ケース(3)「私は気が進まなくても、そして、成功の見込みなんて ものがなくても、彼らの言うとおりにするでしょうね」という発話について考えてみよう。 この発話は、「家族」や「うちに訪れる人たち」によって共有されている（と仮定された） 伝統的治療法への信念に対する距離感を示すことで、個人的な経験や信念について述べて いる。しかしまた、伝統的治療法への信念に対する個人的な距離感が「成功」という概念 を使用して呈示されていることが示唆するように、この発話は「成功率」という科学的基 準を用いて治療の効果が判断される別の文脈にも指向している。その文脈とは、インタ ビューの調査者との間に確立される、近代的治療法に対する信念や科学信仰の共有が仮定 
される文脈である。このように明示化行為では、個別的な経験や信念が明示化される様々 な様式に従って、（しばしば多元／多層的に）文脈が規定される。

明示化行為を通して、明示化される個別的な経験（／発話）と、暗黙に仮定された共有 される経験（／文脈）とが、互いとの差異を通して規定される。明示化とは、未分化な全 体に差異を導入することで、個別的なものと共同的なものを分節化する作用なのである。

このような明示化行為への注目は、現実の共有という事態を、実体論的にではなく関係 論的に考えるための視座を与える。現実の共有は、より安定的で基礎的な過程や機制、ま たは実定的な基準に基づいて成立するものではない。むしろ、現実の共有は、期待に対す る「違背」や「逸脱」「例外」として現れるような特殊な個別経験との差異を通して、そ れらの個別経験との関係の中で、ある種の水位差のようなものとして存立する現象であ る。そして、そのような差異が生まれ関係性が立ち上がるのは、明示化行為によってであ る。別の言い方をすれば、現実の共有は、あくまでもコミュニケーション的現象として考 察されうるのである。このようにDuveenは、明示化という具体的な行為に注目して行為 論的な表象概念を洗練することにより、Wagnerが陥った〈表象の歴史因果的実体化〉を 回避し、コミュニケーション的現象として現実の共有を考えるための新たな視座を提出す ることに成功している。

\section{4. 現実共有論の再構成へ向けて一一実体論から関係論へ}

本稿では、SRTの論考を検討することを通じて、現実共有論における実体論的パース ペクティヴから関係論的パースペクティヴへの視点転換の道筋を素描してきた。この視点 転換を支えるのは、行為論的な表象概念である。従来の現実共有論は、多様な認識間での 同一性や統合の確立を考察することで、現実の共有がなぜ・いかにして成立するのかとい う問いを探究してきた。この問題関心の前提には、表象の認知的機能への排他的関心から、 対象や世界の多様な表象可能性を一定の範囲に制限する過程や規制を行為やコミュニケー ションの背後に探求する、認知主義的な表象概念があるように思われる。それに対して、 SRTの論考は、行為のための仮説としての表象の機能を重視する行為論的な表象概念を 提出することで、コミュニケーション的現象として現実の共有を考察するための新たな視 座を提出している。

実体論と関係論、認知主義的な表象概念と行為論的な表象概念、明示化行為を通した個 別的な経験と共有された経験の分節化。本稿では、今後の研究を進めるうえで鍵となるい くつかの概念や発想を整理することができたが、関係論的パースペクティヴに立つ現実共 有論の全体像を提示するには至っていない。これらの鍵概念や発想同士の関係性を明確に しながら、理論の体系化を図る必要がある。

最後に、行為論的な表象概念との関連で、本稿の議論の位置づけと今後の課題について 述べたい。行為から切り離せないものとして表象を捉える発想は、SRTに特殊なもので はない。たとえば、反表象主義や反認知主義を揭げる論者たちは、表象（／認識）と行為 とを別々の $2 つ の$ 実体や過程とみなす想定が様々な理論的・方法論的混乱を生み出してき たことを主張してきた。また、これらの論者たちによって命題知と方法知の古典的区分や 暗黙知概念の重要性が再発見され、命題知だけでなく方法知が、発話の意味内容だけでな く発話行為の様式が、重要であることが指摘されている。けれども、こうした発想が、社 会や集団に共有された規範や規則、構造化された文化といった、〈社会的なもの〉の領域 
を自明視することも少なくない。個別的な経験と共有された経験を未分化な全体をなすも のとして考え、その全体が分節化される行為に焦点をあてるDuveenの議論は、〈社会的 なもの〉の領域を遂行的に理解するための方途を示している。

また、SRTでは近年、表象とコミュニケーションの関係を語用論的視点から考察する ための取り組みが進められている ${ }^{(7)}$ 。この取り組みによって、社会科学の様々な領域で主 張されてきた「表象の文脈（集団）ごとの多元性」だけでなく、「文脈（集団）の形式的 多元性」を理解することもまた重要であることが認識され始めている。こうした議論を導 きとして、表象と行為、集団といった心理学の概念や理論、方法の前提を問い直しながら、 関係論的パースペクティヴに立つ現実共有論の理論的・実証的基盤を整備していきたい。

\section{註}

（1）たとえば、Schützはまた類型とレリバンス体系の社会的起源や共有を主張することで、独我論的困 難を回避するための道筋を示している [Schütz 1962=1983]。

（2）本稿がここで提案しょうとする方針は、集合的現象の（社会因果的）「説明」ではなく「記述」を指 向するエスノメソドロジストたちの研究方針と近い [Lynch 1993]。けれども、実践への焦点化と同 時に表象の概念を放裹するエスノメソドロジストとは異なり、本稿では行為論的な表象概念を提出す ることで実体論的な発想の転換を試みている。こうした本稿の戦略の意義やそこから導かれる帰結に ついては、別稿で改めて論じることにしたい。

(3) SRTは、現代心理学で支配的な個人主義的パラダイムに対して、意味や経験の社会的構成を主張す るオルタナティヴな社会心理学理論である。

(4) Piagetの著作については現在も様々な解釈がある。本稿ではJovchelovitchによる Piagetの脱中心化 論の要約 [Jovhchelovitch $1995:$ 89-91] のみを参照した。

（5）対象の意味は、対象（刺激）と行為（反応）の関係の全体性という観点から考察される。「共有され た表象」に関するWagnerの議論は、多くの点でJ. Deweyの機能主義的心理学理論の発想に沿うも のと考えられる[Dewey 1896]。

(6) Gillespie [2008]も参照されたい。

( 7 ) Duveen [2008]、Moscovici [1994] を参照のこと。

\section{文献}

Berger, Peter L \& Luckmann, Thomas 1966 The Social Construction of Reality: A Treatise in the Sociology of Knowledge. Doubleday. 山口節郎（訳）『現実の社会的構成：知識社会学論考』新曜社 2003.

Dewey, John 1896 “The Reflex Arc Concept in Psychology," Psychological Review 3: 357-370.

Duveen, Gerald 2007 "Culture and Social Representations," Valsiner, Jaan \& Rosa, Alberto (eds.) 2007 The Cambridge Handbook of Sociocultural Psychology. Cambridge University Press: 543-559.

2008 “Introduction," Moscovici, Serge 2008 Psychoanalysis:Its Image and Its Public. Polity

Garfinkel, Harold 1963 "A Conception of and Experiments with "trust" as a condition of concerted stable actions," Harvey, O. J. (ed.) Motivation and Social Interaction: Cognitive Approaches. Ronald Press: $187-238$.

Gillespie, Alex 2008 "Social Representations, Alternative Representations and Semantic Barriers," Journal for the Theory of Social Behaviour 38(4): 375-391.

Harré, Rom 1998 “The Epistemology of Social Representations," Flick, Uwe (ed.) 1998 The Psychology of the Social. Cambridge University Press: 129-137.

Jovchelovitch, Sandra 1995 "Social Representations in and of the Public Sphere: Towards a Theoretical Articulation," Journal for the Theory of Social Behaviour 25(1): 81-102. 
2007 Knowledge in Context: Representations, Community and Culture. Routledge.

Lynch, Michael 1993 Scientific Practice and Ordinary Action: Ethnomethodology and Social Studies of Science. Cambridge University Press.

Moscovici, Serge 1994 "Social Representations and Pragmatic Communication," Social Science Information 33(2): 163-177.

2008 Psychoanalysis: Its Image and Its Public. Polity. Originally published in La Psychanalyse: Son Image et Son Public. Press Universitaires de France 1961.

Renedo, Alicia \& Jovchelovitch, Sandra 2007 “Expert Knowledge, Cognitive Polyphasia and Health: A Study on Social Representations of Homelessness among Professionals Working in the Voluntary Sector in London," Journal of Health Psychology 12(5): 779-790.

Schütz, Alfred 1932 Der sinnenhafte Aufbau der sozialen welt: Einleitung in der Verstehende Soziologie. Suhrkamp. 佐藤嘉一（訳）『社会的世界の意味構成：ヴェーバー社会学の現象学的分析』木鐸社 1982.

1962 Collected Papers I: The Problem of Social Reality. Martinus Nijhoff. 渡部 光・那須 壽・西 原和久（訳）『アルフレッド・シュッツ著作集＼cjkstart第1巻＼cjkstart社会的現実の問題〔I〕』マルジュ社 1983.

Voelklein, Corina \& Howarth, Caroline 2005 “A Review of Controversies about Social Representations Theory: A British Debate," Culture \& Psychology 11(4): 431-454.

Wagner, Wolfgang 1998 "Social Representations and Beyond: Brute Facts, Symbolic Coping and Domesticated Worlds," Culture \& Psychology 4(3): 297-329.

2007. "Vernacular Science Knowledge: Its Role in Everyday Life Communication," Public Understanding of Science 16(1): 7-22.

Wagner, Wolfgang, Duveen, Gerald, Verma, Jyoti \& Themel, Matthias 1999 “The Modernization of Tradition: Thinking about Madness in Patna, India," Culture \& Psychology 5 (4): 413-445.

2000 “"I have Some Faith and at the Same Time I Don't Believe”: Cognitive Polyphasia and Cultural Change in India," Journal of Community \& Applied Social Psychology 10(4): 301-314.

(一橋大学大学院社会学研究科博士後期課程ｙuri.kumagai75@gmail.com) 